\title{
LABORATORYJNE METODY WYZNACZANIA WSPÓKCZYNNIKA TŁUMIENIA DRGAŃ NA PRZYKŁADZIE GRUNTU SPOISTEGO
}

\author{
Katarzyna Gabryś ${ }^{\bowtie}$, Wojciech Sas, Katarzyna Markowska-Lech, Emil Soból, \\ Andrzej Głuchowski, Jacek Bieniawski
}

Wydział Budownictwa i Inżynierii Środowiska, Szkoła Główna Gospodarstwa Wiejskiego w Warszawie

\begin{abstract}
STRESZCZENIE
Artykuł dotyczy laboratoryjnych metod wyznaczania współczynnika tłumienia gruntu przy wykorzystaniu kolumny rezonansowej. Przedstawiono trzy wybrane metody wyznaczania współczynnika tłumienia w obszarze gruntu: dekrementacji logarytmicznej z krzywej gaśnięcia swobodnych drgań próbki, analizy szerokości pasma połowy mocy oraz histerezy w trybie cyklicznego skrętnego ścinania. Badania przeprowadzono na wybranym gruncie spoistym (ile z pyłem i piaskiem) o nienaruszonej strukturze, pobranym z terenu Kampusu SGGW w Warszawie. W wyniku porównania wartości współczynnika tłumienia wyznaczonego różnymi metodami za uniwersalne podejście dla badanego gruntu uznano krzywą gaśnięcia swobodnych drgań. Ponadto nie stwierdzono stałych korelacji pomiędzy wynikami uzyskanymi odrębnymi metodami.
\end{abstract}

Słowa kluczowe: zjawisko tłumienia, kolumna rezonansowa, grunt spoisty

\section{WSTĘP}

\section{Charakterystyka zjawiska tłumienia}

Tłumienie drgań, będące skutkiem przenikania fali przez ośrodek gruntowy, jest zdolnością do rozproszenia części pracy sił zewnętrznych przy jej zmianie w energię cieplną. Zjawisko to zachodzi w czasie drgań konstrukcji przy cyklicznie zmieniających się naprężeniach. Tłumienie może być definiowane wówczas jako stosunek energii rozproszonej podczas trwania pojedynczego cyklu drgań $(\Delta W)$ do maksymalnej energii dostarczonej do ośrodka w tym samym czasie $(W)$ i opisywane jest wzorem (Salamak, 2003):

$$
\psi=\frac{\Delta W}{W}
$$

gdzie: $\psi$-współczynnik rozproszenia energii.

Do zilustrowania rozproszenia energii w ośrodkach sprężystych można wykorzystać pętlę histerezy (rys. 1). Otrzymuje się ją, badając doświadczalnie zależność między odkształceniem i naprężeniem (Dyka i Srokosz, 2012) lub też na wykresie zależności pomiędzy siłą a wywołanym przez nią przemieszczeniem w ciągu trwania jednego pełnego cyklu obciążenie - odprężenie (Salamak, 2003). 


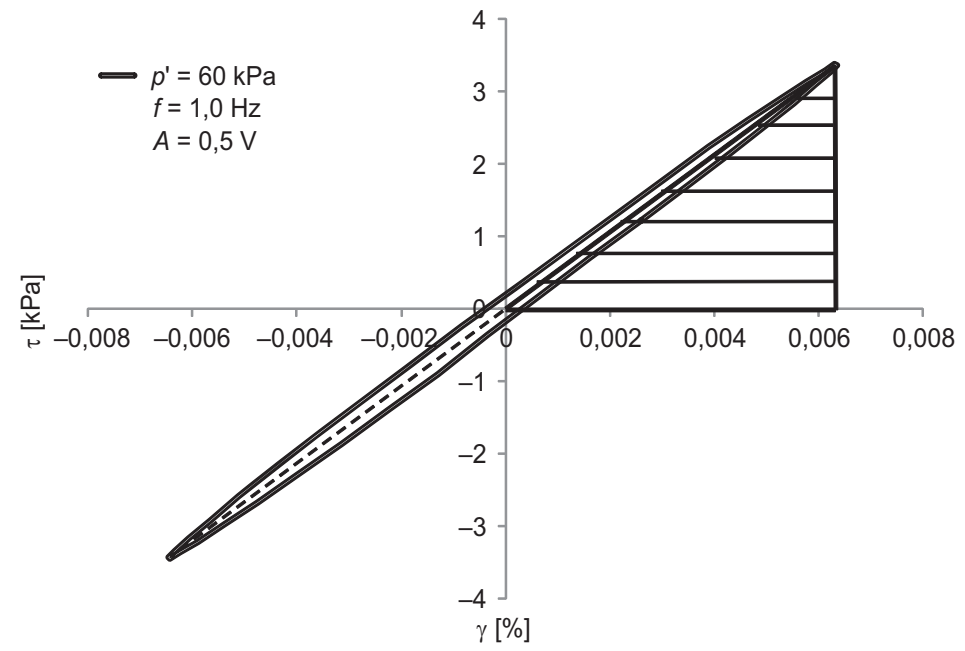

Rys. 1. Przykład pętli histerezy jako zależności między naprężeniem ( $\tau$ ) i odkształceniem ( $\gamma$ ) (Gabryś, Sas i Soból, 2015). Zakreskowana powierzchnia trójkąta reprezentuje maksymalną energię potencjalną zgromadzoną przez materiał próbki

Fig. 1. An example of the hysteresis loop as a relationship between stress ( $\tau$ ) and strain ( $\gamma$ ) (Gabryś, Sas and Soból, 2015). Shaded area of triangular represents the maximum potential energy stored by the specimen

Zjawisko tłumienia drgań jest bardzo złożone. Wyróżnia się trzy główne jego rodzaje. Pierwszy, mający zwykle najmniejszy udział, to thumienie materiałowe. Dotyczy ono zjawisk zachodzących w samym materiale. Drugi to thumienie konstrukcyjne, zależne głównie od obecności tzw. elementów niekonstrukcyjnych w obiekcie i rodzaju połączeń w konstrukcji. Ostatni rodzaj to thumienie zewnętrzne, na które wpływ ma otoczenie konstrukcji (Szulej, 2010).

Tłumienie materiałowe nazywane jest tarciem wewnętrznym. Związane jest ono $\mathrm{z}$ wewnętrzną budową drgającego ciała. Rozproszenie energii wynika ze złożonych zależności pomiędzy molekułami i jest zależne od długości materiału, metod jego wykonania i końcowej obróbki, temperatury oraz naprężenia. Proces thumienia materiałowego zachodzi w kryształach i ma charakter nieodwracalny. Większym thumieniem wewnętrznym charakteryzują się materiały niemetalowe, jak: beton, drewno i guma o dużym tarciu wewnętrznym. Materiały oprostej budowie krystalicznej, np. metale, mają mniejsze tłumienie wewnętrzne.

Tłumienie konstrukcyjne dzielone jest zwykle na dwie grupy: tłumienie tarcia na styku elementów połączonych sztywno oraz tłumienie tarcia połączeń ruchomych. W połączeniach na sztywno w wyniku odkształceń sprężystych dochodzi do poślizgu na stykających się powierzchniach. Opis opiera się na prostych modelach thumienia wiskotycznego Voigta lub Coulomba w zakresie tarcia. Ma ono jednak duży wpływ na redukcję drgań i zależy w głównej mierze od czynników konstrukcyjnych, takich jak: schemat statyczny, wymiary czy kształt konstrukcji.

Tłumienie zewnętrzne, inaczej środowiskowe, opiera się na czynnikach zewnętrznych otoczenia. Odnosi się ono bezpośrednio do gruntu, tłumienia hydrodynamicznego i aerodynamicznego, ale określa również środki transportu. Wpływ tego ośrodka w wielu przypadkach może powodować niebezpieczne drgania, np. na skutek rezonansu (Osiński, 1997).

W obszarach gruntu thumienie zależy od poziomu odkształceń. W przypadku małych odkształceń $\left(\gamma<10^{-3 \%} \%\right)$ występuje tłumienie proporcjonalne do prędkości, dla dużych zaś odkształceń thumienie jest nieproporcjonalne do prędkości odkształceń (rys. 2). 
Gabryś, K., Sas, W., Markowska-Lech, K., Soból, E., Głuchowski, A. i Bieniawski, J. (2017). Laboratoryjne metody wyznaczania współczynnika tłumienia drgań na przykładzie gruntu spoistego. Acta Sci. Pol. Architectura, 16 (3), 13-24. doi: 10.22630/ ASPA.2017.16.3.02.

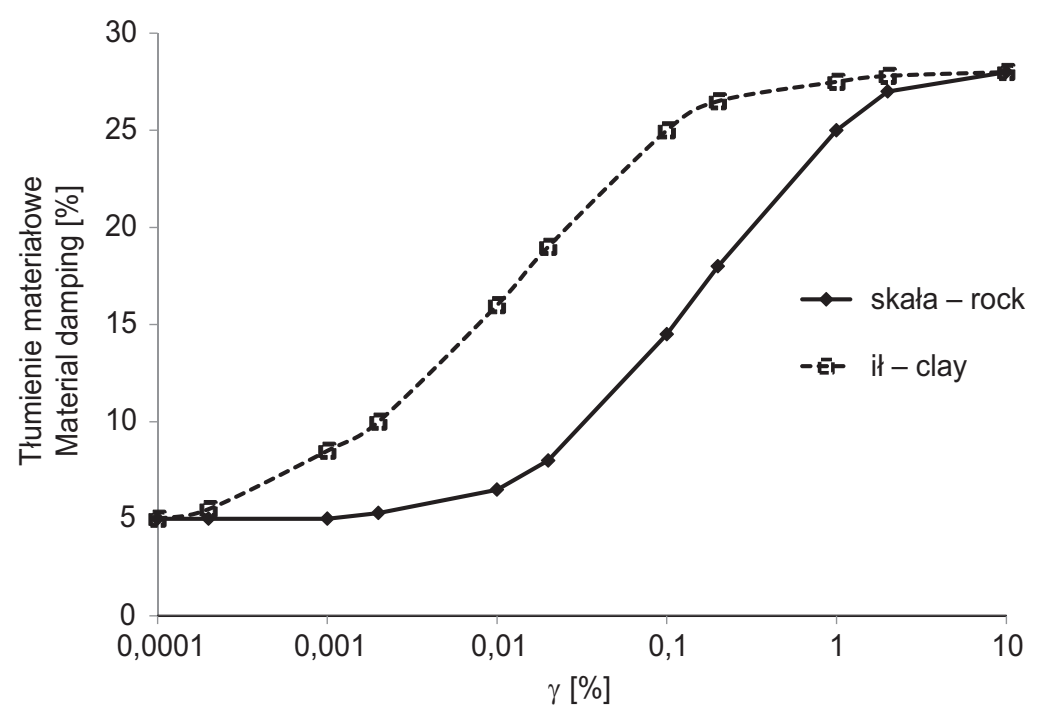

Rys. 2. Tłumienie w gruntach (Wrana i Czado, 2008)

Fig. 2. Damping in soils, according (Wrana and Czado, 2008)

\section{Miary tłumienia}

Do określenia zjawiska tłumienia stosuje się różne miary. Jedną z nich jest stosunek współczynnika tłumienia wiskotycznego do współczynnika tłumienia krytycznego. Zwany jest on najczęściej stopniem thumienia ( $\xi$ ), liczbą thumienia, ułamkiem tłumienia itp. Wyrażany jest w postaci procentu thumienia krytycznego, przy którym następuje zmiana ruchu w aperiodyczny. Stąd wynika jego szerokie wykorzystanie jako parametru porównawczego dla różnych konstrukcji.

Przy doświadczalnym określaniu thumienia stosowany jest zazwyczaj logarytmiczny dekrement thumienia $(\delta)$. Jest to logarytm naturalny stosunku dwóch kolejnych maksymalnych wychyleń (amplitud) - Sas, Gabryś, Soból, Szymański i Głuchowski (2015). Istnieje również pojęcie współczynnika tłumienia (d), odniesionego do drgań nietłumionych (własnych). Kolejną miarą może być, wspomniany wcześniej, współczynnik rozproszenia energii bądź czas zanikania drgań, traktowany podobnie jak okres połowicznego rozpadu w fizyce lub czas stabilizacji drgań. Tłumienie można również określać na podstawie krzywej rezonansowej (funkcji odpowiedzi częstotliwościowej) - Wrana i Czado (2008).

Niniejsza praca dotyczy wyznaczania współczynnik tłumienia $(D)$ drgań propagowanych w gruncie. Parametr ten określa procentowe przejęcie energii propagującej fali przez grunt na stosunkowo krótkim odcinku. Tak definiowany współczynnik tłumienia, postrzegany jako zjawisko naturalne, jest stosowany od wieków, np. przez fortyfikacje polowe. Jednak jego obecne zastosowanie ma znacznie szerszy wymiar w dziedzinach: budownictwa - do projektowania konstrukcji nietypowych, najczęściej zaliczanych do trzeciej kategorii geotechnicznej, energetyki - w celu przeciwdziałania zanikom wielodrogowym przez analizę stref odbicia powierzchni gruntu (Kułakowski, 2003), infrastruktury - w zakresie zasięgu oddziaływania ciągów komunikacyjnych (Niemas, 2004). Ponadto zdolność tłumienia drgań w gruncie jest bardzo istotna w analizie ruchów tektonicznych i związanych z nimi skutków oraz gałęzi przemysłu ściśle związanych z ingerencją w gruncie, np. kopalnictwa i jego efektami (Olszewska, 2008). 
Gabryś, K., Sas, W., Markowska-Lech, K., Soból, E., Głuchowski A. i Bieniawski, J. (2017). Laboratoryjne metody wyznaczania współczynnika tłumienia drgań na przykładzie gruntu spoistego. Acta Sci. Pol. Architectura, 16 (3), 13-24. doi: 10.22630/ ASPA.2017.16.3.02.

\section{MATERIAŁ I METODY}

\section{Badany grunt}

Badania zaprezentowane w niniejszym artykule wykonano w kolumnie rezonansowej, pochodzącej od brytyjskiego koncernu Global Digital Systems Ltd., znajdującej się w Laboratorium - Centrum Wodne SGGW w Warszawie. Materiał badawczy pobrano z terenu Kampusu SGGW w Warszawie (rys. 3), przy ulicy Jana Rodowicza „Anody”. W pobliżu, oprócz budynków Szkoły Głównej Gospodarstwa Wiejskiego, zlokalizowane są bloki mieszkalne, a także wcześniej wspomniana ruchliwa ulica. Głębokość pobrania analizowanego materiału wynosiła około 7,5 m i była determinowana możliwością wykorzystania otrzymanych wyników w przyszłości pod budowę centrum biologii żywienia.

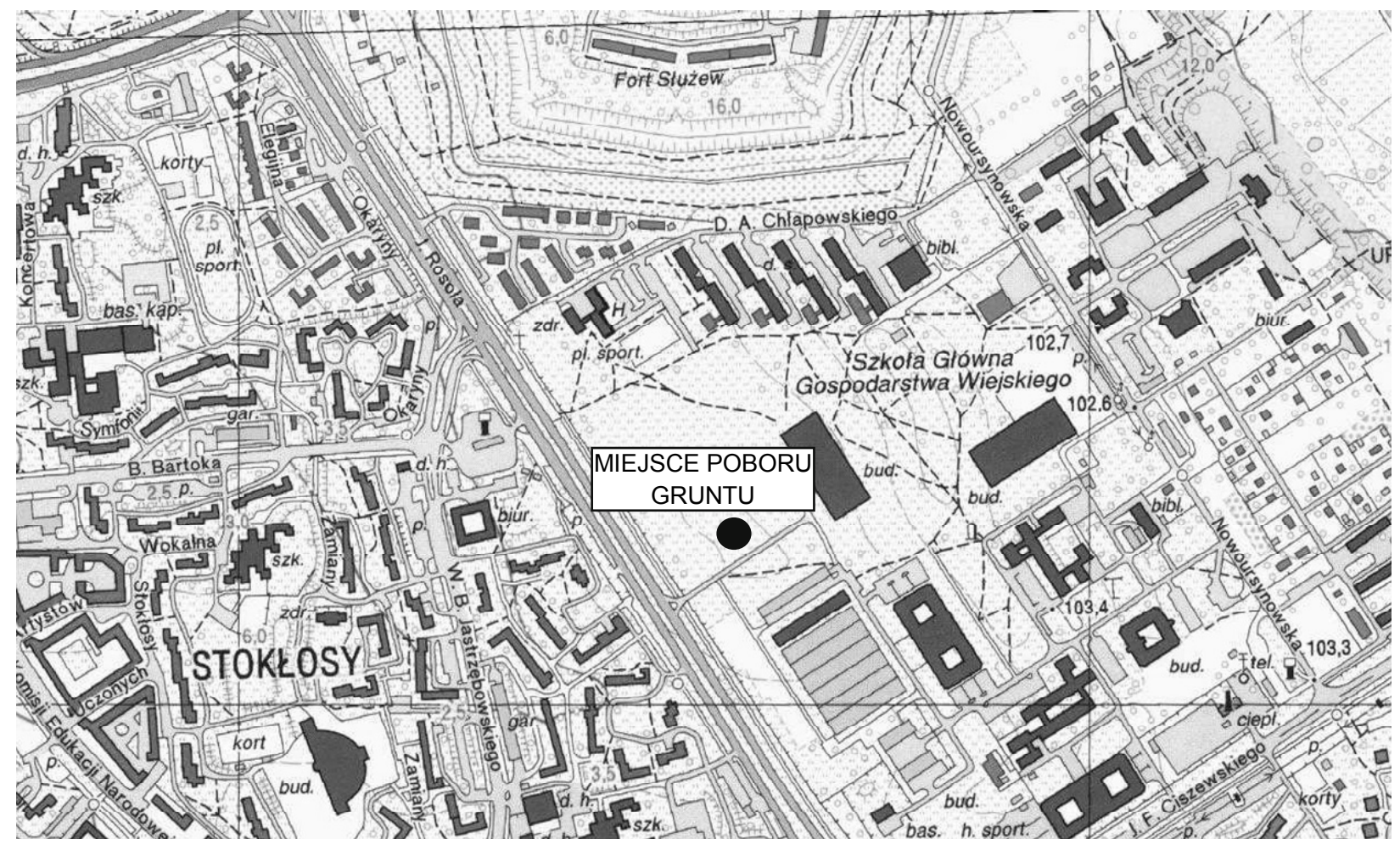

Rys. 3. Lokalizacja miejsca poboru próbki gruntu - czarny punkt (www. geoportal.gov.pl)

Fig. 3. Location of soil sampling - black spot (www.geoportal.gov.pl)

Badany grunt poddano klasyfikacji według normy polskiej PN86/B-02480:1986 oraz europejskiej PN-EN ISO14688-1:2006. Według normy polskiej materiał badawczy sklasyfikowano jako glina piaszczysta $\left(G_{p}\right)$, a według normy europejskiej - ił z pyłem i piaskiem (sasiCl). W tabeli 1 zestawiono wartości wybranych właściwości fizycznych badanego materiału, a na rysunku 4 zaprezentowano jego krzywą uziarnienia. 
Gabryś, K., Sas, W., Markowska-Lech, K., Soból, E., Głuchowski, A. i Bieniawski, J. (2017). Laboratoryjne metody wyznaczania współczynnika tłumienia drgań na przykładzie gruntu spoistego. Acta Sci. Pol. Architectura, 16 (3), 13-24. doi: 10.22630/ ASPA.2017.16.3.02.

Tabela 1. Właściwości fizycznej badanej próbki gruntu

Table 1. Index properties of a tested soil

\begin{tabular}{lccc}
\hline Parametr - Parameter & Symbol - Symbol & Wartość - Value & Jednostka - Unit \\
\hline Gęstość właściwa - Density of solid particles & $\rho_{s}$ & 2,67 & $\mathrm{t} \cdot \mathrm{m}^{-3}$ \\
Gęstość objętościowa - Bulk density & $\rho$ & 2,26 & $\mathrm{t} \cdot \mathrm{m}^{-3}$ \\
Gęstość objętościowa szkieletu - Dry density & $\rho_{d}$ & 2,04 & $\mathrm{t} \cdot \mathrm{m}^{-3}$ \\
Wilgotność - Water content & $w$ & 10,78 & $\%$ \\
Wskaźnik porowatości - Void ratio & $e$ & 0,31 & $\%$ \\
Stopień wilgotności - Degree of saturation & $S_{r}$ & 93 & $\%$ \\
Granica plastyczności - Plastic limit & $w_{P}$ & 13,68 & $\%$ \\
Granica płynności - Liquid limit & $w_{L}$ & 21,50 & - \\
Stopień plastyczności - Liquidity index & $I_{L}$ & $-0,27$ & - \\
Wskaźnik konsystencji - Consistency index & $I_{C}$ & 1,37 &
\end{tabular}

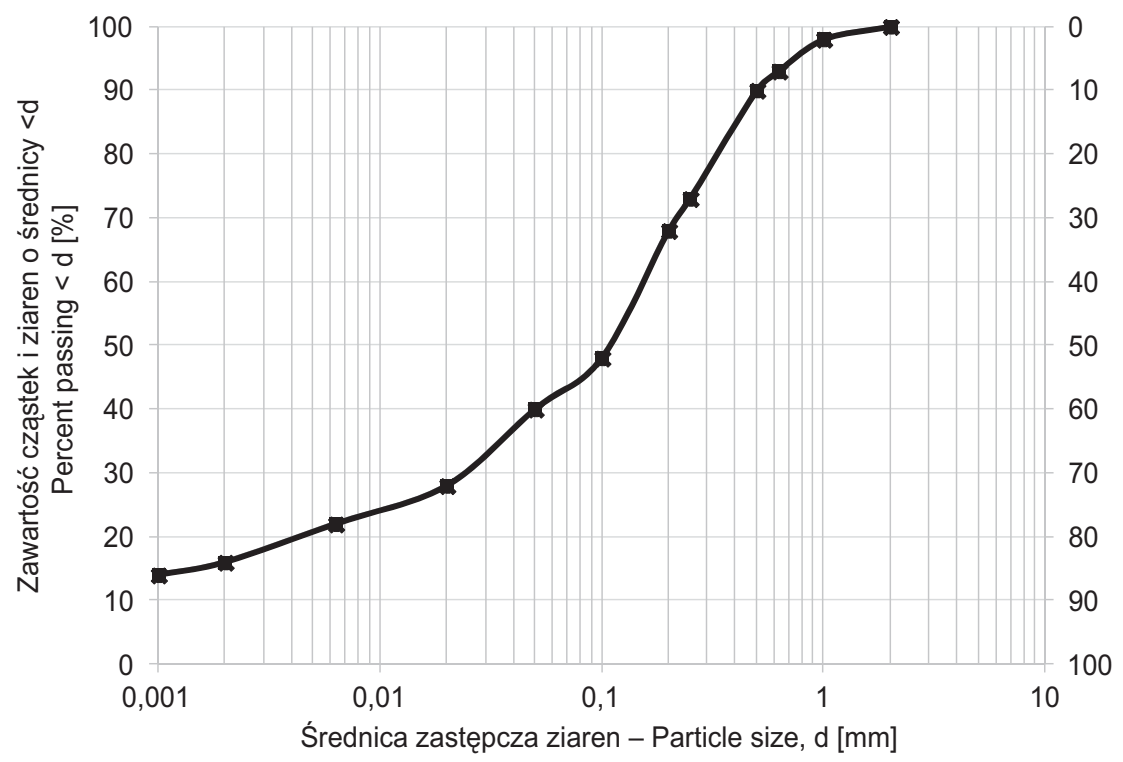

Rys. 4. Krzywa uziarnienia badanej próbki gruntu

Fig. 4. Grain size distribution of a tested soil 


\section{Metody wyznaczania współczynnika tłumienia}

W niniejszym artykule rozważane jest zagadnienie wyznaczania thumienia w gruncie przy zastosowaniu kolumny rezonansowej. Ideę badania w tym urządzeniu oraz jego szerokie możliwości badawcze przedstawiono m.in. w pracach: Sas i Gabryś (2012); Gabryś i in. (2013); Sas i in. (2015); Soból, Sas i Szymański (2015).

Celem dotychczasowych artykułów było jednakże wyznaczenie modułu odkształcenia postaciowego $(G)$ i modułu odkształcenia $(E)$. Współczynnik zaś thumienia $(D)$ często pomijano w badaniach ze względu na trudną interpretację i niedoskonałą metodykę badania.

Do identyfikacji współczynnika thumienia wykorzystano trzy metody:

- dekrementację logarytmiczną z krzywej gaśnięcia swobodnych drgań próbki,

- analizę szerokości pasma połowy mocy,

- histerezę w trybie cyklicznego, skrętnego ścinania.

Metoda dekrementacji logarytmicznej z krzywej gaśnięcia swobodnych drgań próbki gruntu. Krzywa gaśnięcia swobodnych drgań próbki (KGSD - free-vibration decay curve) tworzona jest na podstawie zapisu amplitudy drgań $(\Theta)$ z akcelerometru umieszczonego na płycie systemu napędowego kolumny rezonansowej. W momencie uzyskania drgań o stałej mocy ich wzbudzanie ustaje, a wytłumiane przez próbkę wibracje są stopniowo zapisywane przez komputer. Proces ten pozwala na wyznaczenie dekrementacji logarytmicznej $(\delta)$, tj. stosunku następujących po sobie amplitud $(\Theta)$ w ruchu thumionym (rys. 5), na tej podstawie można oszacować współczynnik tłumienia (oznaczany na potrzeby pracy symbolem $D_{K G S D}$ ) zgodnie ze wzorem (Soból i in., 2015):

$$
\begin{gathered}
D_{K G S D}=\sqrt{\frac{\delta^{2}}{4 \pi^{2}+\delta^{2}}} \\
\delta=\frac{1}{n} \cdot \ln \left(\frac{\Theta_{1}}{\Theta_{n+1}}\right)
\end{gathered}
$$

gdzie: $n$ - liczba cykli pomiędzy dwoma największymi wychyleniami łączącymi obwiednię thumienia,

$\Theta_{1}$ - amplituda drgań pierwszego cyklu po wyłączeniu zasilania,

$\Theta_{1+n}$ - amplituda drgań $(n+1)$ cykli zaistniałych od momentu wyłączenia zasilania.

Tak zdefiniowany współczynnik tłumienia można opisać jako tempo wyrównywania do położenia równowagi największych wychyleń z ruchu drgającego.

Metoda analizy szerokości pasma połowy mocy. Określenie współczynnika tłumienia z metody analizy szerokości pasma połowy mocy (PMP - half-power bandwith), inna nazwa - metody modalnej (Wrana i Czado, 2008), opiera się na uproszczonej interpretacji trzech wartości częstotliwości w czasie: częstotliwości rezonansowej oraz dwóch pozostałych, przed rezonansem i po nim, równo oddalonych od częstotliwości rezonansowej o jej iloraz $\sqrt{2}$ (rys. 6). Współczynnik thumienia (oznaczany na potrzeby pracy symbolem $D_{P M P}$ ) obliczany jest zatem ze wzoru (Papagiannopoulos i Hatzigeorgiou, 2011):

$$
D_{P M P}=\frac{\omega_{2}-\omega_{1}}{2 \omega_{n}}
$$

gdzie: $\omega_{n}-$ naturalna częstość drgań własnych nietłumionych,

$\omega_{1}$ - częstość drgań tłumionych przed rezonansem,

$\omega_{2}-$ częstość drgań thumionych po rezonansie. 
Gabryś, K., Sas, W., Markowska-Lech, K., Soból, E., Głuchowski, A. i Bieniawski, J. (2017). Laboratoryjne metody wyznaczania współczynnika tłumienia drgań na przykładzie gruntu spoistego. Acta Sci. Pol. Architectura, 16 (3), 13-24. doi: 10.22630/ ASPA.2017.16.3.02.

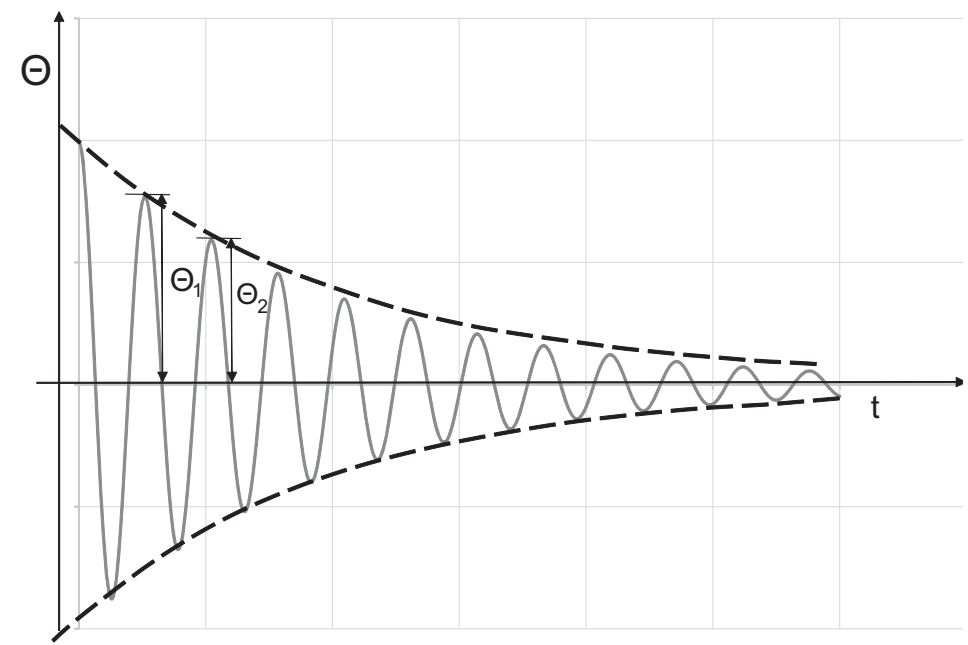

Rys. 5. Krzywa gaśnięcia swobodnych drgań próbki gruntu (GDS, 2010): $\Theta$ - amplituda drgań, $t$ - czas

Fig. 5. Free-vibration decay curve of a tested soil, according (GDS, 2010): $\Theta$ - amplitude of cycle, $t$ - time

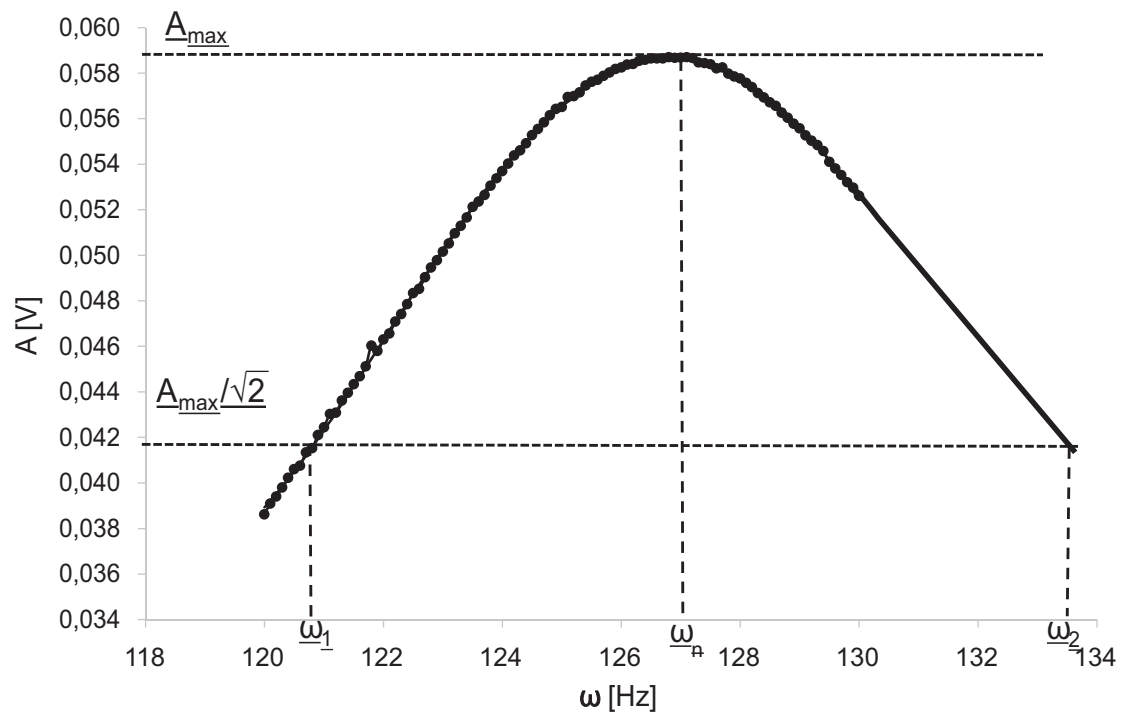

Rys. 6. Interpretacja graficzna metody PMP na przykładzie $p^{\prime}=150 \mathrm{kPa}$ i $A=0,01 \mathrm{~V}: A$ - amplituda fali, $\omega-$ częstość kątowa drgań

Fig. 6. The half-power bandwidth method for $p^{\prime}=150 \mathrm{kPa}$ and $A=0.01 \mathrm{~V}: A$ - shearing strain amplitude, $\omega-$ excitation frequency

W praktyce naturalna częstotliwość $\left(\omega_{n}\right)$ może zostać zastąpiona przez częstotliwość rezonansową $\left(\omega_{r}\right)$, która jest pozyskiwana $\mathrm{z}$ badań rezonansowych. $\mathrm{Z}$ uwagi na ujęcie częstotliwości rezonansowej jako kluczowej do wyznaczenia współczynnika tłumienia krytycznego metoda ta jest również nazywana metodą rezonansową. Znajduje ona zastosowanie w konstrukcjach budowli naziemnych, zazwyczaj żelbetowych lub stalowych, przy założeniu liniowego zachowania się konstrukcji, wyznaczania globalnego współczynnika thumienia, która ma ograniczone zastosowanie do obszaru gruntu (Wrana i Czado, 2008). 
Gabryś, K., Sas, W., Markowska-Lech, K., Soból, E., Głuchowski A. i Bieniawski, J. (2017). Laboratoryjne metody wyznaczania współczynnika tłumienia drgań na przykładzie gruntu spoistego. Acta Sci. Pol. Architectura, 16 (3), 13-24. doi: 10.22630/ ASPA.2017.16.3.02.

Metoda odczytu $z$ histerezy $w$ trybie cyklicznego, skrętnego ścinania. Badanie w trybie cyklicznego, skrętnego ścinania (CSS - torsional shear test) polega na cyklicznym obciążaniu próbki momentem skrętnym o zmieniającej się harmonicznie wartości, o częstotliwości zmian poniżej $10 \mathrm{~Hz}$. Powoduje to wywołanie w badanym gruncie składowej stycznej stanu naprężenia. Dzięki uzyskaniu wartości składowych stycznych $(\tau)$ i odkształceń postaciowych w czasie $(\gamma)$ można określić wartości energii rozproszonej i pochłoniętej przez próbkę gruntu podczas cyklicznego skręcania (Dyka i Srokosz, 2014). Zapis graficzny uzyskanych wyników przedstawiono na rysunku 1 . Uzyskane wartości współczynnika tłumienia (oznaczany na potrzeby pracy symbolem $D_{C S S}$ ) opisuje się wzorem:

$$
D_{C S S}=\frac{1}{2 \pi} \cdot \frac{W_{D}}{E_{P}}
$$

gdzie: $W_{D}$ - energia pochłaniana przez materiał podczas cyklicznego skręcania, inaczej energia rozpraszana, reprezentowana na rysunku 1 przez pole histerezy opisanej zależnością funkcyjną $\tau(\gamma)$,

$E_{P}$ - energia potencjalna, charakteryzująca chwilową kumulację energii przez materiał w stanie maksymalnego odkształcenia $\left(\gamma_{\max }\right)$, inaczej energia odkształceń, definiowana jako pole trójkąta pod wykresem liniowo-sprężystej reakcji materiału badanej próbki.

\section{WYNIKI}

Do analizy porównawczej wartości współczynnika tłumienia drgań propagowanych w badanym gruncie spoistym, ile z pyłem i piaskiem przyjęto dane uzyskane z badania tłumienia przy różnych wartościach średniego naprężenia efektywnego $\left(p^{\prime}\right)$, odpowiednio: 75,150 oraz $225 \mathrm{kPa}$. Badanie wybranej próbki gruntu przebiegało $\mathrm{w}$ trzech etapach. Pierwszym etapem było nasączanie materiału badawczego metodą ciśnienia wyrównawczego. Każdorazowo przeprowadzano kontrolę stanu nasycenia próbki poprzez określenie wartości parametru Skemptona $(B)$. Kolejny etap to izotropowa konsolidacja, którą przeprowadzono przy trzech, wcześniej wymienionych, różnych naprężeniach efektywnych. Ostatnim etapem badania, po zakończeniu każdej konsolidacji, był pomiar współczynnika tłumienia $\mathrm{w}$ warunkach $\mathrm{z}$ odpływem. Badania tłumienia przeprowadzono przy różnych wartościach zadawanego momentu wymuszenia generowanego zakresem napięcia elektrycznego od 0,002 V dla metody KGSD do $1,0 \mathrm{~V}$ dla metody CSS.

W tabeli 2 zestawiono wyniki obliczeń współczynnika tłumienia uzyskane z trzech opisanych wcześniej metod. Wszystkie wartości współczynnika thumienia podane są w procentach. Dodatkowo są to wartości średnie z dziesięciu pomiarów wykonanych w zależności od liczby cykli branych do kalkulacji. Zdaniem Sobola $\mathrm{i}$ innych (2015), prawidłowa liczba cykli uwzględniona w wyznaczaniu parametru tłumienia gruntu drobnoziarnistego znajduje się w pewnym przedziale - między 10 . a 20 . cyklem. W prezentowanych badaniach dla amplitudy fali do wartości $0,01 \mathrm{~V}$ założono liczbę cykli nie większą niż 10, bowiem fala między 10. a 20. cyklem była już całkowicie wytłumiona. Dla większych amplitud natomiast do obliczenia parametru $D$ założono liczbę cykli pomiędzy 10 a 20 . Ponadto w przypadku wyznaczania współczynnika tłumienia histerezą $\left(D_{C S S}\right)$ badania przeprowadzono w dwóch wariantach obciążeniowych - przy częstotliwości 1,0 Hz oraz $10 \mathrm{~Hz}$.

Analizując wartości $D_{K G S D}$, można zaobserwować stałą tendencję wzrostu thumienia fali przez ośrodek gruntowy wraz ze wzrostem jej początkowej amplitudy, bez względu na wartość średniego naprężenia efektywnego. Wyniki współczynnika tłumienia wyznaczonego z interpretacji szerokości połowy pasma mocy $\left(D_{P M P}\right)$ również charakteryzuje ciągły wzrost wartości, łącznie o $27 \%$, przy postępowym wzroście amplitudy od wartości $0,004 \mathrm{~V}$ do wartości $0,5 \mathrm{~V}$ dla naprężeń przekraczających wartość naprężenia in situ wynoszącą $170 \mathrm{kPa}$. Podobną tendencję zmian można zauważyć w przypadku wartości $D_{C S S}$, za wyjątkiem $D_{C S S}$ dla $p^{\prime}=225 \mathrm{kPa}$ i $f=10 \mathrm{~Hz}$, gdzie uzyskane wyniki nie są w jakiś sposób, rosnący bądź malejący, uszeregowane. Oszacowano średni wzrost 
Gabryś, K., Sas, W., Markowska-Lech, K., Soból, E., Głuchowski, A. i Bieniawski, J. (2017). Laboratoryjne metody wyznaczania współczynnika tłumienia drgań na przykładzie gruntu spoistego. Acta Sci. Pol. Architectura, 16 (3), 13-24. doi: 10.22630/ ASPA.2017.16.3.02.

Tabela 2. Wartości współczynnika tłumienia uzyskane metodami KGSD, PMP i CSS

Table 2. Results of damping ratio from free-vibration decay curve, half-power bandwidth and torsional shear methods

\begin{tabular}{|c|c|c|c|c|c|c|c|c|c|c|c|c|}
\hline \multirow{5}{*}{ 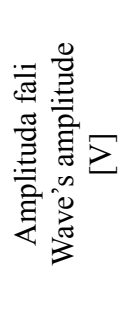 } & \multicolumn{12}{|c|}{ Metoda - Method } \\
\hline & \multirow{2}{*}{\multicolumn{3}{|c|}{$\begin{array}{c}\text { Krzywa gaśnięcia } \\
\text { swobodnych drgań } \\
\text { Free-vibration decay curve }\end{array}$}} & \multirow{2}{*}{\multicolumn{3}{|c|}{$\begin{array}{l}\text { Połowa mocy pasma } \\
\text { Half-power bandwidth }\end{array}$}} & \multirow{2}{*}{\multicolumn{3}{|c|}{$\begin{array}{c}\text { Cykliczne skrętne ścinanie } \\
1 \mathrm{~Hz} \\
\text { Torsional shear } 1 \mathrm{~Hz}\end{array}$}} & \multirow{2}{*}{\multicolumn{3}{|c|}{$\begin{array}{c}\text { Cykliczne skrętne ścinanie } \\
10 \mathrm{~Hz} \\
\text { Torsional shear } 10 \mathrm{~Hz}\end{array}$}} \\
\hline & & & & & & & & & & & & \\
\hline & \multicolumn{12}{|c|}{ Średnie naprężenie efektywne - Mean effective stress [kPa] } \\
\hline & 75 & 150 & 225 & 75 & 150 & 225 & 75 & 150 & 225 & 75 & 150 & 225 \\
\hline 0,002 & & 3,07 & & & 5,80 & 5,91 & & & & & & \\
\hline 0,003 & & 3,41 & & & 5,25 & & & & & & & \\
\hline 0,004 & & 3,70 & 3,39 & 5,19 & 4,84 & 4,65 & & & & & & \\
\hline 0,005 & & 3,53 & 3,56 & & 4,84 & 4,61 & & & & & & \\
\hline 0,006 & & 3,43 & 3,61 & 5,04 & 4,69 & 4,65 & & & & & & \\
\hline 0,007 & & 3,71 & 3,71 & & 4,96 & 4,89 & & & & & & \\
\hline 0,008 & 4,20 & 3,83 & 3,73 & 4,94 & & 4,82 & & & & & & \\
\hline 0,009 & 4,23 & 3,94 & 3,75 & & 4,90 & 4,86 & & & & & & \\
\hline 0,01 & 4,25 & 4,12 & 3,88 & 4,82 & 4,91 & 5,00 & & & & & & \\
\hline 0,02 & 4,83 & 4,14 & 3,87 & 5,10 & 4,85 & 4,91 & & & & & & \\
\hline 0,03 & 5,06 & 4,31 & 3,96 & 4,68 & 4,75 & 4,80 & & & & & & \\
\hline 0,04 & 5,11 & 4,28 & 4,13 & 4,83 & 5,43 & 4,91 & 1,46 & 1,58 & 0,53 & & & \\
\hline 0,05 & 5,26 & 4,31 & 4,17 & & 5,10 & 4,89 & 1,62 & 1,72 & 1,32 & 3,63 & 3,68 & 3,96 \\
\hline 0,06 & 5,34 & 4,39 & 4,20 & & 5,31 & 4,78 & 1,65 & 1,69 & 1,26 & 3,62 & 2,00 & 4,47 \\
\hline 0,07 & 5,37 & 4,53 & 4,27 & & 5,28 & 4,79 & 1,46 & 1,55 & 1,53 & 4,10 & 3,27 & 3,49 \\
\hline 0,08 & 5,49 & 4,44 & 4,28 & & 5,24 & 4,88 & 1,59 & 1,52 & 1,74 & 5,21 & 2,61 & 4,22 \\
\hline 0,09 & 5,63 & 4,55 & 4,29 & & 5,23 & 4,87 & 1,61 & 1,62 & 1,21 & 5,61 & 2,88 & 2,86 \\
\hline 0,1 & 5,84 & 4,57 & 4,36 & & 5,24 & 5,02 & 1,55 & 1,66 & 1,61 & 5,17 & 4,81 & 3,12 \\
\hline 0,2 & 6,65 & 5,10 & 4,75 & & 5,48 & 4,98 & 1,64 & 1,59 & 1,70 & 4,84 & 4,58 & 2,91 \\
\hline 0,3 & 7,75 & 5,71 & 5,21 & & 5,78 & 5,01 & 1,58 & 1,81 & 1,68 & 5,57 & 3,40 & 2,80 \\
\hline 0,4 & 8,84 & 6,28 & 5,65 & 7,20 & 6,08 & 5,71 & 1,69 & 1,85 & 1,72 & 3,99 & 4,22 & 3,83 \\
\hline 0,5 & 9,95 & 7,18 & 6,33 & & 6,96 & 5,92 & 1,78 & 2,10 & 1,81 & 4,21 & 3,45 & 2,95 \\
\hline 0,6 & & & 6,87 & & & 10,25 & 2,06 & 2,23 & 1,91 & 4,32 & 3,69 & 3,22 \\
\hline 0,7 & & & & & & & 2,03 & 2,35 & 1,97 & 5,51 & 3,62 & 4,52 \\
\hline 0,8 & & & & & & & 2,27 & 2,54 & 2,10 & 5,16 & 3,30 & 3,24 \\
\hline 0,9 & & & & & & & 2,36 & 2,65 & 2,41 & 5,08 & 5,14 & 3,95 \\
\hline 1,0 & & & & & & & 2,61 & 2,75 & 2,37 & 4,92 & 4,56 & 3,38 \\
\hline
\end{tabular}


Gabryś, K., Sas, W., Markowska-Lech, K., Soból, E., Głuchowski A. i Bieniawski, J. (2017). Laboratoryjne metody wyznaczania współczynnika tłumienia drgań na przykładzie gruntu spoistego. Acta Sci. Pol. Architectura, 16 (3), 13-24. doi: 10.22630/ ASPA.2017.16.3.02.

wartości $D_{C S S}$ przy częstotliwości zmian obciążenia $1,0 \mathrm{~Hz}$ i zmianie amplitudy od 0,04 do $1,0 \mathrm{~V}$ na poziomie około 55\%. Dla badania cyklicznego, skrętnego ścinania przy $f=10 \mathrm{~Hz}$ obliczono, że średni wzrost współczynnika thumienia, przy odpowiednim wzroście amplitudy fali, wynosi około $23 \%$.

W następnej kolejności dokonano analizy wartości współczynnika tłumienia wyznaczonego w zakresie małych odkształceń. Na podstawie odpowiednich pozycji naukowych, np. Zhang, Andrus i Juang (2005), wartość tego parametru dla małych odkształceń nie zmienia się, a sam parametr w rozpatrywanym przedziale jest określany symbolem $D_{\min }$. Przy większych odkształceniach natomiast nieliniowość w relacji naprężenie - odkształcenie prowadzi do wzrostu thumienia wraz ze wzrostem amplitudy odkształcenia.

Zestawienie $D_{\min }$ dla każdej z metod (rys. 7) pozwala scharakteryzować zależność pomiędzy trzema analizowanymi metodami (KGSD, PMP, CSS) jako stałą, jednak nie jest to w pełni wiarygodne odzwierciedlenie z uwagi na brak możliwości odnoszenia powstałej zależności zmian dla każdego rodzaju gruntu. W wyniku czego reakcja gruntu nie tworzy zależności matematycznej łączącej wszystkie metody dla danej próbki gruntu, a tym bardziej uniwersalnej zależności dla dowolnego gruntu.

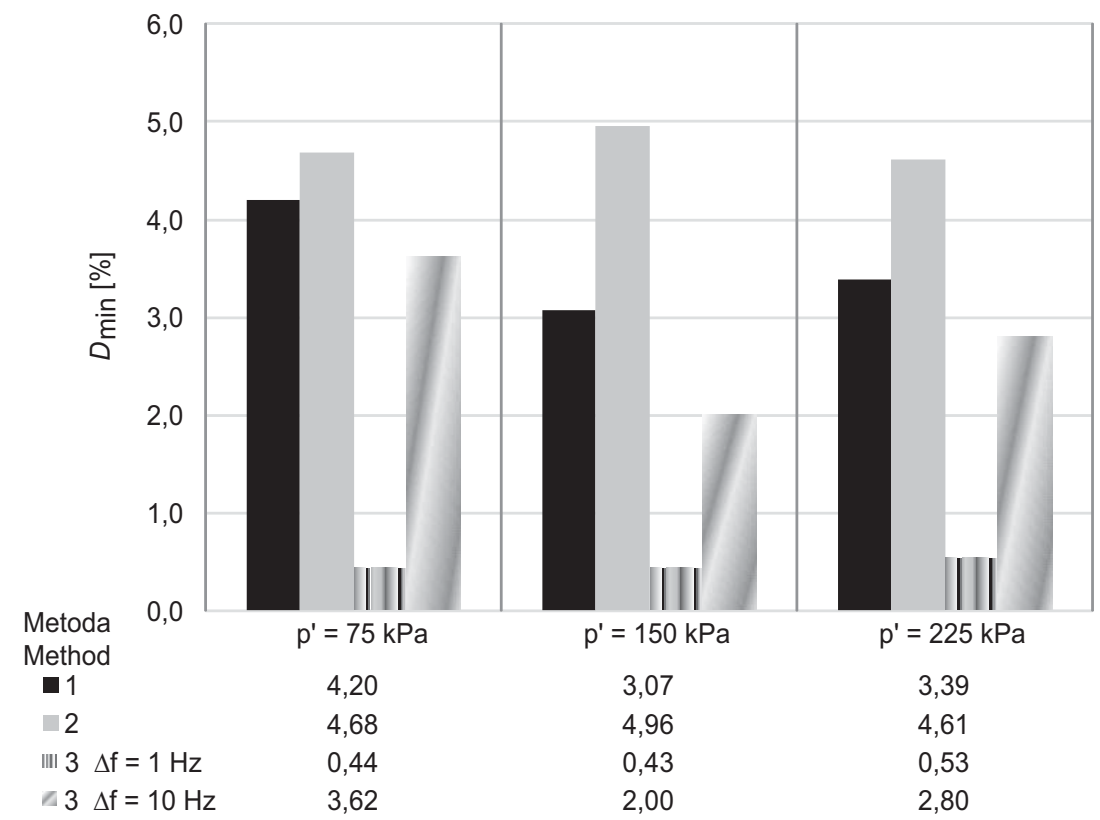

Rys. 7. Porównanie wartości $D_{\min } \mathrm{z}$ analizowanych metod przy różnym średnim naprężeniu efektywnym: 1 - krzywa gaśnięcia swobodnych drgań, 2 - połowa mocy pasma, 3 - cykliczne skrętne ścinanie

Fig. 7. Comparison of $D_{\min }$ values from the analyzed methods at different mean effective stress: 1 - free-vibration decay curve, 2 - half-power bandwidth, 3 - torsional shear

Tym niemniej na podstawie wykonanej analizy wyników można zauważyć, że największe wartości $D_{\min }$ uzyskano z metody PMP (średnia $D_{\min \text { PMP }}=4,66 \%$ ), następnie z metody KGSD (średnia $D_{\operatorname{min~KGSD}}=3,55 \%$ ) oraz CSS dla $f=10 \mathrm{~Hz}$ (średnia $D_{\min \text { CSS }}=2,81 \%$ ), a na końcu z metody CSS dla $f=1 \mathrm{~Hz}$ (średnia $D_{\operatorname{mincss}}=0,41 \%$ ). Wyraźnie widoczna redukcja w wartościach $D_{\min }$ jest z przedziału od 24 do $90 \%$, w zależności od zastosowanej metody. Trudno jest natomiast zaobserwować jednoznaczny wpływ samego średniego naprężenia efektywnego ( $p$ ’) na właściwości tłumienia badanego iłu z pyłem i piaskiem. 
Gabryś, K., Sas, W., Markowska-Lech, K., Soból, E., Głuchowski, A. i Bieniawski, J. (2017). Laboratoryjne metody wyznaczania współczynnika tłumienia drgań na przykładzie gruntu spoistego. Acta Sci. Pol. Architectura, 16 (3), 13-24. doi: 10.22630/ ASPA.2017.16.3.02.

Dalsza analiza rysunku 7 pozwala stwierdzić istnienie zależności między tłumieniem a odprężeniem gruntu na skutek badania próbki poza warunkami in situ. Dla najmniejszej wartości naprężenia, tj. $75 \mathrm{kPa}$ (z wyłączeniem metody PMP, z uwagi na brak znacznej części odczytów współczynnika thumienia - patrz tab. 2), $D_{\min }$ jest większe od jego wartości dla większych naprężeń. Szczególnie jest to obserwowane dla metody CSS przy częstotliwości $10 \mathrm{~Hz}$. Świadczyć to może o rozluźnieniu szkieletu gruntowego w wyniku długotrwałego zdjęcia naprężenia od rodzimego nadkładu. Pozwala to w konsekwencji wnioskować, iż rozluźniony grunt ma większe zdolności tłumiące.

\section{PODSUMOWANIE I WNIOSKI}

W niniejszym artykule przedstawiono zagadnienie identyfikacji współczynnika tłumienia w warunkach laboratoryjnych przy wykorzystaniu standardowej oraz zmodyfikowanej kolumny rezonansowej (wyposażonej w aparat skrętnego ścinania). Rozważano trzy różne metody wyznaczania współczynnika tłumienia: KGSD, PMP i CSS. Z przeprowadzonych badań wypływają następujące wnioski:

1. Metodę dekrementacji logarytmicznej z krzywej gaśnięcia swobodnych drgań próbki można uznać za najlepsze i zarazem uniwersalne podejście obliczeniowe współczynnika thumienia dla badanego gruntu spoistego, iłu z pyłem i piaskiem, z terenu Warszawy dla określonych warunków brzegowych. Jest to podyktowane analizą gaśnięcia drgań każdorazowo przypisanych do konkretnej próbki gruntu, co z kolei pozwala określić uzyskany rodzaj thumienia jako tłumienie liniowe dla jednorodnej próbki gruntu. Tłumienie wyznaczone tą metodą (KGSD), inaczej zwane thumieniem wiskotycznym z uwagi na udział wody wypełniającej przestrzenie między ziarnami badanego gruntu, może mieć inną formę dla gruntów pęczniejących, wymaga to jednak dalszych badań.

2. Odzwierciedlenie rozpraszanej energii, które analizowane jest w metodzie CSS, jest lepiej widoczne dla większych częstotliwości zmian $(f=10 \mathrm{~Hz})$ i obrazuje wzrost rozpraszania energii przy wzroście odkształcenia na skutek gwałtownej reakcji gruntu. W wyniku tego metoda cyklicznego skrętnego ścinania jest dobrym obrazem propagacji fali w ośrodku gruntowym, ale dla zjawisk krótkotrwałych, o wysokiej częstotliwości, np. wstrząsów górniczych wywoływanych kontrolowanym wybuchem.

3. Dokonana analityczna próba porównania wartości współczynnika tłumienia $D_{K G S D}$ ze współczynnikiem $D_{C S S}$, zaproponowana przez Dykę i Srokosza (2014), nie ma potwierdzenia w otrzymanych wynikach badań. Zdaniem Dyki i Srokosza (2014), wartość parametru $D$ uzyskana z metody KGSD odpowiada połowie wartości $D$ z badań CSS. W przypadku niniejszych badań średnia wartość porównawcza $D_{K G S D} / D_{C S S}$ wynosi 0,3 dla częstotliwości obciążenia $1,0 \mathrm{~Hz}$ oraz 0,73 dla $f=10 \mathrm{~Hz}$.

4. Należy kontynuować badania laboratoryjne nad współczynnikiem tłumienia innych rodzajów gruntów, nie uwzględnionych w tym artykule, w kierunku wysnucia szerszych, popartych analizą statystyczną wniosków.

\section{PIŚMIENNICTWO}

Dyka, I. i Srokosz, P. (2012). Badania gruntu w aparacie skrętnego ścinania RC/TS. Część 1. Inżynieria Morska i Geotechnika, 6, 700-707.

Dyka, I. i Srokosz, P. (2014). Badania gruntu w aparacie skrętnego ścinania RC/TS. Część 2. Inżynieria Morska i Geotechnika, 2, 118-129.

Gabryś, K., Sas, W. i Szymański, A. (2013). Kolumna rezonansowa jako urządzenie do badań dynamicznych gruntów spoistych. Przeglad Naukowy Inżynieria i Kształtowanie Środowiska, 59, 3-13.

Gabryś, K., Sas, W. i Soból, E. (2015). Small-strain dynamic characterization of clayey soil from Warsaw. Acta Scientiarum Polonorum Architectura, 14 (1), 55-65.

GDS Resonant Column (2010). The GDS Resonant Column System Handbook (Version 2.2.2010). 
Gabryś, K., Sas, W., Markowska-Lech, K., Soból, E., Głuchowski A. i Bieniawski, J. (2017). Laboratoryjne metody wyznaczania współczynnika tłumienia drgań na przykładzie gruntu spoistego. Acta Sci. Pol. Architectura, 16 (3), 13-24. doi: 10.22630/ ASPA.2017.16.3.02.

Kułakowski, P. (2003). Analiza wpływu warunków terenowo-klimatycznych na pracę systemów radiokomunikacyjnych. Praca magisterska. Kraków: Akademia Górniczo-Hutnicza.

Niemas, M. (2004). Ciężki ruch kołowy i jego wpływ na klimat wibroakustyczny w warunkach mieszkalnych. Prace Instytutu Techniki Budowlanej, 2 (130), 43-54.

Olszewska, D. (2008). Ocena efektów lokalnych i struktury częstotliwościowej sygnałów sejsmometrycznych dla poprawy dokładności prognozy rozprzestrzeniania drgań wzbudzonych wstrzasami górniczymi w Legnicko-Głogowskim Okręgu Miedziowym. (rozprawa doktorska). Kraków: Akademia Górniczo-Hutnicza.

Osiński, Z. (1997). Ttumienie drgań. Warszawa: Wydawnictwo Naukowe PWN.

Papagiannopoulos, G. i Hatzigeorgiou, G.D. (2011). On the use of the half-power bandwidth method to estimate damping in building structures., Soil Dynamics and Earthquake Engineering, 31, 1075-1079.

PN-B-02480:1986. Grunty budowlane. Określenia, symbole, podział i opis gruntów.

PN-EN ISO 14688-1:2006. Badania geotechniczne. Oznaczenie i klasyfikowanie gruntów. Część 1: Oznaczenie i opis.

Salamak, M. (2003). Doświadczalne metody określania poziomu tłumienia drgań w kładkach dla pieszych. (rozprawa doktorska). Gliwice: Politechnika Śląska.

Sas, W. i Gabryś, K. (2012). Laboratory measurement of shear stiffness in resonant column apparatus. Acta Scientiarium Polonorum, Architectura, 11 (4), 29-39.

Sas, W., Gabryś, K., Soból, E., Szymański, A. i Głuchowski, A. (2015). Stiffness and damping of selected cohesive soils based on dynamic laboratory tests. W M. Dobiszewska (red.), Wybrane zagadnienia konstrukcji i materiatów budowlanych oraz geotechniki. (strony 325-332). Bydgoszcz: Wydawnictwa Uczelniane Uniwersytetu Technologiczno-Przyrodniczego.

Soból, E., Sas, W. i Szymański, A. (2015). Zastosowanie kolumny rezonansowej do określenia reakcji gruntów drobnoziarnistych obciążonych dynamicznie. Przegląd Naukowy Inżynieria i Kształtowanie Środowiska, 68, 133-144.

Szulej, J. (2010). Wyznaczenie ekwiwalentnego wiskotycznego tlumienia drgań w konstrukcjach wielomateriałowych. (rozprawa doktorska). Lublin: Politechnika Lubelska.

Wrana, B. i Czado, B. (2008). Identyfikacja tłumienia w gruncie. Górnictwo i Geoinżynieria, 32 (2), 329-336.

Zhang, J.F., Andrus, R.D. i Juang, C.H. (2005). Normalized Shear Modulus and Material Damping Ratio Relationships. Journal of Geotechnical and Geoenvironmental Engineering, ASCE, 131 (4), 453-464.

\section{LABORATORY METHODS FOR DETERMINATION OF DAMPING RATIO ON THE EXAMPLE OF COHESIVE SOIL}

\section{SUMMARY}

The paper concerns the laboratory methods for determination of damping ratio in soil in resonant column apparatus. In the paper three selected methods for damping's evaluation were presented: free vibration decay, half-power bandwidth and hysteresis from cyclic torsional shear. Laboratory tests were carried out on selected cohesive, undisturbed soil (clay with silt and sand), collected from the campus of WULS-SGGW in Warsaw. Based on the comparison between $D$ values from different methods, free vibration decay was regarded as a universal approach for the examined soil. Furthermore, no fixed correlation between the results obtained by separate methods was observed.

Key words: damping phenomenon, resonant column, cohesive soil 